\title{
Pathological Effects of Benomyl in Male Japanese Quails (Coturnix japonica)
}

\author{
M. Z. KHAN ${ }^{1}$, SAJJAD-UL-HASSAN ${ }^{1}$, F. MAHMOOD ${ }^{1}$, Q. M. KHAN ${ }^{3}$, G. MUHAMMAD ${ }^{2}$, I. JAVED ${ }^{4}$ \\ ${ }^{1}$ Department of Veterinary Pathology, University of Agriculture, Faisalabad, Pakistan \\ ${ }^{2}$ Clinical Medicine and Surgery, University of Agriculture, Faisalabad, Pakistan \\ ${ }^{3}$ National Institute for Biotechnology and Genetic Engineering, Faisalabad, Pakistan \\ ${ }^{4}$ Physiology and Pharmacology, University of Agriculture, Faisalabad, Pakistan
}

Received April 23, 2007

Accepted February 14, 2008

\begin{abstract}
Khan M. Z., Sajjad-U1-Hassan, F. Mahmood, Q. M. Khan, G. Muhammad, I. Javed: Pathological Effects of Benomyl in Male Japanese Quails (Coturnix japonica). Acta Vet. Brno 2008, 77: 209-216.

The purpose of this experimental study was to observe the pathological and genotoxic effects of a systemic fungicide, Benomyl [methyl 1-(butyl carbamoyl)-2 benzimidazole carbamate] in male Japanese quails (Coturnix japonica). Benomyl (Benlate ${ }^{\circledR}$ DoPont 50\% w/w benomyl) at dose rates of $0,100,400$ and $1000 \mathrm{mg} / \mathrm{kg}$ for 8 consecutive days was administered into crops of quails kept in different groups. A significant decrease $(p<0.05)$ in feed intake, body weight and relative weight of testes was observed in benomyl-administered quails in a dose related manner. The size of testes decreased in benomyl treated quails. Microscopically, seminiferous tubules of testes exhibited a decreased number of spermatocytes, necrotic spermatids and syncytial cell formation. The number of quails developing testicular alterations increased in a dose-related pattern. These alterations reversed following a withdrawal of benomyl with the exception of the $1000 \mathrm{mg}$ benomyl group, where these persisted till the end of the experiment $\left(56^{\text {th }}\right.$ day). The mean tail length $(\mu \mathrm{m})$ of the comets produced by leukocytes in single cell gel electrophoresis of 0,100 and $400 \mathrm{mg}$ dose level groups were 3.48, 3.24 and 3.29, respectively. The mean tail length of comets of the $1000 \mathrm{mg}$ dose level group was $12.03 \mu \mathrm{m}$ and significantly higher $(p<0.01)$ than in all other groups indicating DNA strand breaks at this dose level. These results suggested gonadotoxic effects of benomyl (Benlate ${ }^{\sqrt{ }}$ ) and also a possible genotoxic effect at $1000 \mathrm{mg} / \mathrm{kg}$ level in Japanese quails.
\end{abstract}

Benomyl pathology, quails, testes, DNA damage, Comet assay

Benomyl [methyl 1-(butyl carbamoyl)-2 benzimidazole carbamate] is a systemic fungicide for a broad spectrum application at pre- and post-harvest stages of various food crops, fruits and vegetables. Benomyl and its primary metabolite, carbendazim, [methyl 2-benzimidazole carbamat], have been shown to be gonadotoxic and to induce a decrease in fertility, viability of sperm cells, decreased testes weight and testicular abnormalities in rats and dogs (Carter et al. 1987; Barnes et al. 1983; Linder et al. 1988; Hess and Nakai 2000; Rajeswary et al. 2007). Exposure of rat embryos cultured in vitro provided evidence that benomyl was a potential developmental toxicant affecting many indicators of differentiation, including optic development (Hewitt et al. 2005). Benomyl and carbendazim are also known as aneuploidogens resulting in numerical chromosomal aberrations in vivo and in mammalian cells in vitro (Bentley et al. 2000). There are conflicting reports of genotoxic effects of benomyl as tested by in vitro/in vivo techniques (Adhikari and Grover 1988). Many reports have described benomyl and carbendazim to give negative results in bacterial reverse gene mutation assays and/or bacterial DNA damage/repair tests (McCarroll et al. 2002). However, bone marrow micronucleus assays showed that benomyl and carbendazim resulted in significantly increased micronucleated polychromatic erythrocytes (Seiler 1976; Sarrif et al. 1994). Apart from domestic and wild mammals, birds living in the same ecological system and searching feed in the fields

Address for correspondence:

M. Zargham Khan DVM PhD

Dept. Veterinary Pathology,

University of Agriculture, Faisalabad, 38040

PAKISTAN
Phones: +92 (041) 2619403

+92 (041) 9200161. Ext. 3119

E-mail: mzargham2000@yahoo.com

http://www.vfu.cz/acta-vet/actavet.htm 
treated with benomyl are also exposed to this compound. Considerable data on the effects of benomyl and its metabolite upon mammalian species are available in the literature. However, only one report described the carbendazim-induced pathological changes in testes of Japanese quails (Aire 2005) and no report described genotoxic effects in avian species. This paper describes the experimentally induced pathological and genotoxic effects of benomyl in male Japanese quails (Coturnix japonica).

\section{Materials and Methods}

Experimental birds, feed and layout

A total of 96 male Japanese quails of 43 days of age, free from any apparent clinical ailment, procured from a local quail farm were placed in metallic wire cages at ambient temperature and provided a 12/12 hours period of light/dark. A corn soybean meal-based feed (total protein $23 \%$ ) and water was offered ad libitum for the duration of the experiment. Quails after one week of acclimatization and at attaining sexual maturity were divided into 4 groups (A, B, C, and D) of 24 birds each. Each group was kept in a separate cage. Benlate ${ }^{2}$ (DUPONT), a fungicidal preparation containing benomyl and inert ingredients $(50 \% \mathrm{w} / \mathrm{w})$ was used as a source of benomyl. Benlate ${ }^{\circledR}$ suspended in corn oil was administered directly into the crop of each bird using a crop tube for eight consecutive days. Dose level of Benlate ${ }^{\circledR}$ for each quail in groups A - D was calculated to provide $0,100,400$ and $1000 \mathrm{mg}$ of benomyl $/ \mathrm{kg}$ body weight, respectively. Concentrations of benomyl in corn oil for different groups were prepared so that one $\mathrm{ml}$ of corn oil contained one dose.

The experiment lasted for 56 days, starting from the day of the first treatment with benomyl. Six birds from each group were humanely killed on days 8,14, 28 and 56 of the experiment. The experiment was conducted following approval by the Directorates of Research, Advanced Studies and with the consent of Society of Ethics of Animals, University of Agriculture, Faisalabad, Pakistan. Killing of the birds was performed as per rules laid down by the Society of Ethics of Animals, University of Agriculture, Faisalabad, Pakistan.

Clinical evaluation

Birds in different groups were monitored and evaluated subjectively twice daily for clinical signs and behavioural alterations using different indicators including (i) alertness, (ii) attraction to feed, (iii) response on disturbance and (iv) crowing. Feed intake of each group was recorded on daily basis. The body weight of individual quails in each group was recorded weekly.

Pathology procedures

Visceral organs of each sacrificed quail were examined for the presence of gross lesions. Testes, liver, heart, kidneys and spleen were weighed and their relative weight was calculated as a percentage of the body weight. Tissues of about $5 \mathrm{~mm}$ thickness obtained from the middle portion of the testes were fixed in 10\% neutral buffered formalin. These tissues were processed for histopathological examination using a routine paraffin-wax embedding method. Sections of $5 \mu \mathrm{m}$ thickness were stained with haematoxylin and eosin.

Collection and storage of blood leukocytes

Venous blood was collected from each bird killed at day 8 of the experiment into a tube containing EDTA (2 $\mathrm{mg} / \mathrm{ml}$ ) as an anticoagulant. Blood was centrifuged to separate plasma and cells. The buffy coat (leukocytes) of each blood sample was collected into an Eppendorf tube and stored at $-20^{\circ} \mathrm{C}$.

Single cell gel electrophoresis

The alkaline single cell gel electrophoresis of leukocytes was performed as described (Singh et al. 1988). All the chemicals used were obtained from Sigma (Sigma St. Louis, MO USA). Comets were identified as a diffused "cloud" of DNA material fluorescing around the nuclei or making a tail in the direction of the electric field. Tail lengths of 50 comets, in each slide, were measured from the edge of each nucleus using a calibrated ocular micrometer.

\section{Statistical analysis}

The data obtained were subjected to statistical analysis using an analysis of variance test. The group means were compared by Duncan's multiple range test. Data on tail lengths of comets of different groups were compared by $t$-test, using the statistical software package (M-Stat). The level of significance was $p \leq 0.05$.

\section{Results}

\section{Clinical signs and behavioural alterations}

Within five minutes of benomyl administration, quails of different groups showed depression. This depression lasted for ca $1 \mathrm{~h}$. For this reason all observations were recorded 2 and $8 \mathrm{~h}$ after the administration of benomyl. Clinical signs and behavioural alterations during the experiment included a reduced desire to feed and drink (attraction towards feed 
and water) and reduced responses to disturbance. Benomyl-dosed quails also exhibited a decreased frequency of crowing. All the signs and behavioural alterations occurred in a dose-related manner, being most intense in group $\mathrm{D}$, most subtle in group $\mathrm{B}$ and absent in controls (group A). After cessation of the benomyl administration, the clinical signs and behavioural alterations gradually returned to normal. This return to normal behaviour also occurred in a dose-related manner, being earliest to disappear in group B (day 11 of the experiment) and latest in group D (day 14 of the experiment).

Body weight

Body weights of the quails (Table 1) of groups $\mathrm{C}$ and D on day 14 were significantly lower than of the control birds (group A). On days 21, 28 and 35, all the treatment groups had significantly lower body weights than the control birds. However, on day 56 there was no significant difference in the body weight between the control group and treated groups.

Table 1. Body weights $(\mathrm{G})$ of Japanese quails administered different levels of benomyl (mean $\pm \mathrm{SE}$ )

\begin{tabular}{|c|c|c|c|c|}
\hline \multirow{2}{*}{ Days } & \multicolumn{4}{|c|}{ Groups } \\
\cline { 2 - 5 } & $\begin{array}{c}\text { A } \\
0 \mathrm{mg} / \mathrm{kg} \text { b.wt. }\end{array}$ & $\begin{array}{c}\text { B } \\
100 \mathrm{mg} / \mathrm{kg} \text { b.wt. }\end{array}$ & $\begin{array}{c}\mathrm{C} \\
400 \mathrm{mg} / \mathrm{kg} \text { b.wt. }\end{array}$ & $\begin{array}{c}\mathrm{D} \\
1000 \mathrm{mg} / \mathrm{kg} \mathrm{b} . w t .\end{array}$ \\
\hline 7 & $96.83 \pm 1.83$ & $103.63 \pm 1.43$ & $100.06 \pm 0.61$ & $94.87 \pm 1.60$ \\
\hline 14 & $121.83 \pm 2.07 \mathrm{a}$ & $112.17 \pm 2.24 \mathrm{ab}$ & $110.50 \pm 3.17 \mathrm{~b}$ & $102.83 \pm 3.52 \mathrm{~b}$ \\
\hline 21 & $133.50 \pm 4.46 \mathrm{a}$ & $120.50 \pm 2.43 \mathrm{~b}$ & $114.67 \pm 3.64 \mathrm{~b}$ & $112.33 \pm 2.46 \mathrm{~b}$ \\
\hline 28 & $139.00 \pm 4.77 \mathrm{a}$ & $122.67 \pm 4.03 \mathrm{~b}$ & $125.67 \pm 2.32 \mathrm{~b}$ & $112.00 \pm 4.41 \mathrm{~b}$ \\
\hline 35 & $136.67 \pm 4.41 \mathrm{a}$ & $123.67 \pm 4.96 \mathrm{~b}$ & $114.17 \pm 5.04 \mathrm{bc}$ & $111.17 \pm 4.11 \mathrm{c}$ \\
\hline 42 & $144.37 \pm 3.45 \mathrm{a}$ & $133.64 \pm 2.76 \mathrm{~b}$ & $151.03 \pm 2.22 \mathrm{a}$ & $127.17 \pm 3.85 \mathrm{~b}$ \\
\hline 49 & $143.50 \pm 3.84 \mathrm{a}$ & $137.17 \pm 4.54 \mathrm{ab}$ & $142.17 \pm 9.09 \mathrm{ab}$ & $132.00 \pm 2.07 \mathrm{~b}$ \\
\hline 56 & $149.50 \pm 3.84$ & $136.17 \pm 3.49$ & $144.83 \pm 2.86$ & $130.17 \pm 4.26$ \\
\hline
\end{tabular}

Values in each row followed by different letters are statistically different $(p<0.05)$

Feed intake

Feed intake (g/bird/day) of Japanese quails (Table 2) in all treatment groups remained significantly lower than that of control till day 35 of the experiment with the decrease occurring in a dose-related manner. On days 42, 49 and 56, the feed intake of quails in groups $C$ and D was not significantly different from that of the control group (A), however, group B showed a significantly higher feed intake than controls on days 42 and 56.

Table 2. Feed intake of male Japanese quails administered different levels of benomyl (mean $\pm \mathrm{SE})$

\begin{tabular}{|c|c|c|c|c|}
\hline \multirow{2}{*}{ Days } & \multicolumn{4}{|c|}{ Groups } \\
\cline { 2 - 5 } & $\begin{array}{c}\text { A } \\
0 \mathrm{mg} / \mathrm{kg} \text { b.wt. }\end{array}$ & $\begin{array}{c}\text { B } \\
100 \mathrm{mg} / \mathrm{kg} \text { b.wt. }\end{array}$ & $\begin{array}{c}\mathrm{C} \\
400 \mathrm{mg} / \mathrm{kg} \mathrm{b} . w t .\end{array}$ & $\begin{array}{c}\mathrm{D} \\
1000 \mathrm{mg} / \mathrm{kg} \mathrm{b} . w t .\end{array}$ \\
\hline 7 & $21.22 \pm 0.41 \mathrm{a}$ & $17.26 \pm 0.40 \mathrm{~b}$ & $10.55 \pm 0.10 \mathrm{c}$ & $9.57 \pm 0.30 \mathrm{c}$ \\
\hline 14 & $23.33 \pm 0.30 \mathrm{a}$ & $18.51 \pm 0.60 \mathrm{~b}$ & $14.09 \pm 1.27 \mathrm{c}$ & $11.64 \pm 1.173 \mathrm{~d}$ \\
\hline 21 & $22.11 \pm 0.80 \mathrm{a}$ & $18.61 \pm 0.81 \mathrm{~b}$ & $14.63 \pm 0.80 \mathrm{c}$ & $13.92 \pm 0.76 \mathrm{c}$ \\
\hline 28 & $22.55 \pm 0.75 \mathrm{a}$ & $17.22 \pm 0.54 \mathrm{~b}$ & $15.49 \pm 0.88 \mathrm{~b}$ & $16.94 \pm 0.65 \mathrm{~b}$ \\
\hline 35 & $23.39 \pm 0.25 \mathrm{a}$ & $17.11 \pm 0.24 \mathrm{bc}$ & $16.33 \pm 0.71 \mathrm{c}$ & $18.83 \pm 0.78 \mathrm{~b}$ \\
\hline 42 & $22.55 \pm 0.36 \mathrm{a}$ & $20.36 \pm 1.03 \mathrm{~b}$ & $20.55 \pm 1.06 \mathrm{ab}$ & $21.50 \pm 0.50 \mathrm{ab}$ \\
\hline 49 & $21.75 \pm 0.83 \mathrm{~b}$ & $24.08 \pm 0.20 \mathrm{a}$ & $22.00 \pm 0.93 \mathrm{~b}$ & $21.17 \pm 0.49 \mathrm{~b}$ \\
\hline 56 & $22.17 \pm 0.59 \mathrm{bc}$ & $24.33 \pm 0.49 \mathrm{a}$ & $22.50 \pm 0.58 \mathrm{ab}$ & $20.33 \pm 0.40 \mathrm{c}$ \\
\hline
\end{tabular}

Values in each row followed by different letters are statistically different $(p<0.05)$

Organ weights

The mean relative weights (Table 3 ) of testes on day 8 of the experiment were significantly lower in groups B, C and D compared with group A. On days 14 and 28, group B 
differed non-significantly from group A, whereas groups C and D had significantly lower relative testicular weights from that of group A. On day 56 quails of group D had significantly lower weights of testes than the control birds.

Table 3. Relative weights of different organs of quails administered 4 different levels of benomyl in crop (mean $\pm \mathrm{SE})$

\begin{tabular}{|c|c|c|c|c|}
\hline \multirow{3}{*}{ Days } & \multicolumn{4}{|c|}{ Groups } \\
\cline { 2 - 5 } & $\begin{array}{c}\text { A } \\
0 \mathrm{mg} / \mathrm{kg} \text { b.wt. }\end{array}$ & $\begin{array}{c}\text { B } \\
100 \mathrm{mg} / \mathrm{kg} \text { b.wt. }\end{array}$ & $\begin{array}{c}\mathrm{C} \\
400 \mathrm{mg} / \mathrm{kg} \text { b.wt. }\end{array}$ & $\begin{array}{c}\text { D } \\
1000 \mathrm{mg} / \mathrm{kg} \text { b.wt. }\end{array}$ \\
\cline { 2 - 5 } & \multicolumn{4}{|c|}{ Testes } \\
\hline 8 & $1.99 \pm 0.08 \mathrm{a}$ & $1.70 \pm 0.05 \mathrm{~b}$ & $0.62 \pm 0.22 \mathrm{c}$ & $0.49 \pm 0.26 \mathrm{c}$ \\
\hline 14 & $1.77 \pm 0.22 \mathrm{a}$ & $1.69 \pm 0.13 \mathrm{a}$ & $1.05 \pm 0.19 \mathrm{~b}$ & $0.71 \pm 0.24 \mathrm{~b}$ \\
\hline 28 & $2.13 \pm 0.31 \mathrm{a}$ & $2.06 \pm 0.40 \mathrm{a}$ & $1.04 \pm 0.10 \mathrm{~b}$ & $1.14 \pm 0.12 \mathrm{~b}$ \\
\hline 56 & $1.73 \pm 0.13 \mathrm{a}$ & $1.92 \pm 0.41 \mathrm{a}$ & $1.88 \pm 0.34 \mathrm{a}$ & $1.24 \pm 0.07 \mathrm{~b}$ \\
\hline & $2.17 \pm 0.27 \mathrm{~b}$ & $2.56 \pm 0.14 \mathrm{ab}$ & $2.81 \pm 0.17 \mathrm{a}$ & $2.89 \pm 0.08 \mathrm{a}$ \\
\hline 8 & $1.88 \pm 0.09 \mathrm{~b}$ & $2.13 \pm 0.25 \mathrm{ab}$ & $1.67 \pm 0.16 \mathrm{~b}$ & $2.40 \pm 0.09 \mathrm{a}$ \\
\hline 28 & $1.38 \pm 0.12$ & $1.81 \pm 0.14$ & $1.67 \pm 0.13$ & $1.84 \pm 0.16$ \\
\hline 56 & $1.41 \pm 0.07$ & $1.66 \pm 0.26$ & $1.72 \pm 0.10$ & $1.53 \pm 0.14$ \\
\hline
\end{tabular}

Values in each row followed by different letters are statistically different $(p<0.05)$

The relative weight of the liver on day 8 was significantly higher in groups C and D. On day 14 those in group D had a significantly higher liver weight compared to group A. Relative weights of the spleen, kidney and heart of quails of all groups did not differ significantly from each other throughout the experiment and hence are not presented.

Gross lesions

Testes of quails from all treatment groups showed a decrease in size in comparison with controls as shown in Table 4 . On days 8 and 14 of the experiments smaller testes were present in quails of all benomyl-dosed groups, and their number increased in a dose-related pattern, being highest in group D. On days 28 and 56 smaller testes were observed only in group D. Lesions in other organs on day 8 comprised of petechial haemorrhages in the thigh muscles of quails in all benomyl-dosed groups. Livers were lighter in colour and moderately enlarged in groups $\mathrm{C}$ and $\mathrm{D}$. No gross lesions were observed in quails killed on other days.

Table 4. Number (percent) of quails having smaller* testes in benomyl dosed groups

\begin{tabular}{|c|c|c|c|c|}
\hline \multirow[b]{2}{*}{ Days } & \multicolumn{4}{|c|}{ Groups } \\
\hline & $\begin{array}{c}\mathrm{A} \\
0 \mathrm{mg} / \mathrm{kg} \text { b.wt. }\end{array}$ & $\begin{array}{c}\text { B } \\
100 \mathrm{mg} / \mathrm{kg} \text { b.wt. }\end{array}$ & $\begin{array}{c}\mathrm{C} \\
400 \mathrm{mg} / \mathrm{kg} \text { b.wt. }\end{array}$ & $\begin{array}{c}\mathrm{D} \\
1000 \mathrm{mg} / \mathrm{kg} \text { b.wt. }\end{array}$ \\
\hline 8 & $0(0)$ & $2(33)$ & $3(50)$ & $5(83)$ \\
\hline 14 & $0(0)$ & $3(50)$ & $2(33)$ & $6(100)$ \\
\hline 28 & $0(0)$ & $0(0)$ & $0(0)$ & $6(100)$ \\
\hline 56 & $0(0)$ & $0(0)$ & $0(0)$ & $2(33)$ \\
\hline
\end{tabular}

*In comparison with testes of quails from group A

Histopathology

Cells at all stages of spermatogenesis were represented in the seminiferous tubules of control quails in group A slaughtered at different stages of the experiment.

In group B, on day 8 of the experiment, smaller testes had seminiferous tubules lined by spermatogonia and spermatocytes but no spermatids or spermatozoa were present. On day 14 the seminiferous tubules of two out of six quails had darkly stained pyknotic nuclei in 
round spermatids. Elongated spermatids and young spermatozoa were not present in the tubules. On days 28 and 56 one quail at each sampling time had pyknotic nuclei in the round spermatids.

In group $\mathrm{C}$, on day 8 of the experiment, quails having smaller testes showed pyknotic nuclei of round spermatids and no spermatozoa were present in the seminiferous tubules. A similar pattern was observed in two out of six quails killed on days 14 and 28. On day 56 the histological picture of the testes of all the quails was similar to that of the control birds.

In quails of group D, on day 8 the testes from two birds had two to three layers of cells lining the seminiferous tubules. In other quails the lumens of many tubules contained a mixture of desquamated germinal epithelial cells. On day 14 the seminiferous tubules of four quails had fewer spermatocytes when compared to those of the control birds and a few or no bunches of young spermatozoa were present in the tubules. In two birds large syncytial cells with up to eight nuclei were present in the germinal epithelial layer. On day 28 , the germinal epithelium comprised of spermatogonia, spermatocytes and spermatids but no young spermatozoa. Empty spaces were frequently present between the cells. The population density of these cells was lower than those of controls. In many tubules round spermatids had dark pyknotic nuclei. On day 56 of the experiment, two quails with smaller testes had the same histological picture as on day 28 while in the other birds the tubules appeared similar to those of the control group.

Table 5. Tail lengths of the comets produced by DNA extracted from leukocytes of male Japanese quails treated with four different doses of benomyl

\begin{tabular}{|l|c|c|c|c|}
\hline $\begin{array}{l}\text { Comet tail } \\
\text { length }(\mu \mathrm{m})\end{array}$ & $\begin{array}{c}\text { Group A } \\
\text { number }(\%)\end{array}$ & $\begin{array}{c}\text { Group B } \\
\text { number }(\%)\end{array}$ & $\begin{array}{c}\text { Group C } \\
\text { number }(\%)\end{array}$ & $\begin{array}{c}\text { Group D } \\
\text { number }(\%)\end{array}$ \\
\hline Less than 5 & $296(98.7)$ & $297(99.1)$ & $293(97.7)$ & $195(65.0)$ \\
\hline$>5 \leq 10$ & $4(1.4)$ & $3(1.0)$ & $7(2.3)$ & $20(6.7)$ \\
\hline$>10 \leq 30$ & 0 & 0 & 0 & $42(14.0)$ \\
\hline$>30 \leq 50$ & 0 & 0 & 0 & $31(10.3)$ \\
\hline$>50$ & 0 & 0 & 0 & $12(4.0)$ \\
\hline
\end{tabular}

Single Cell Gel Electrophoresis Assay

The comets were observed as DNA material fluorescing around the nuclei and making a "tail" of variable length along the electric field (Table 5). In groups A, B and C, over 97\% of the comets had a tail length of less than $5 \mu \mathrm{m}$, while the remaining $3 \%$ had a tail length ranging from 5 to $10 \mu \mathrm{m}$. Comet tails in these groups were present in a diffuse form around the nuclei. In group D, $65 \%$ of the cells had comet tails with lengths of less than $5 \mu \mathrm{m}$, $6.17 \%$ from $5-10 \mu \mathrm{m}$ and remaining $(28.3 \%)$ more than $10 \mu \mathrm{m}$. The mean tail lengths of the comets ( \pm standard deviation) produced by the leukocytes of groups A, B, C and D was $3.48 \pm 1.21,3.24 \pm 1.29,3.29 \pm 1.34$ and $12.032 \pm 19.35$ micrometers, respectively. $T$-test performed on the data showed that groups B and C differed non-significantly from the control group, while group D had a significantly $(p \leq 0.01)$ higher tail length compared to all other groups.

\section{Discussion}

Acute and chronic toxicity of benomyl has been well established in mammals by various workers both in field and experimental conditions. However, information about its toxicity

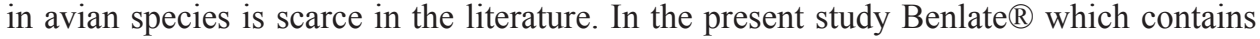
$50 \%$ benomyl $(\mathrm{w} / \mathrm{w})$ was used as a source of benomyl. Dose levels of benomyl and the duration of exposure were decided arbitrarily as no toxicological data was available in avian species. Clinical signs and behavioural alterations of the quails in the present study 
were non-specific. A decrease in crowing in the high dose groups correlated with depressed sexual activity that might have been a result of testicular lesions observed following benomyl administration. However, alterations have not been reported in sexual behaviour of Japanese quails (Aire 2005) fed carbendazim (a metabolite of benomyl) and also in rat and mice (Barnes et al. 1983; Linder et al. 1988) following benomyl administration.

A significant decrease in the body weight of the benomyl-treated quails occurred concurrently with a decrease in the feed intake suggesting that the latter could have been the cause of decreased body weight. A decrease in the feed intake and body weight has been reported previously in rats and mice given benomyl (Hurtt et al. 1993; Warheit et al. 1989). However, Rajeswary et al. (2007) mentioned no effect of carbendazim on the body weight of rats. The most consistent finding in the benomyl-treated quails was a decrease in weights of testes that occurred in a dose-related pattern. Similarly Aire (2005) also reported a decrease in the weight of testes exposed to benomyl. Benomyl and its metabolite carbendazim have been reportedly found to be toxic for the male reproductive system in mammalian species and a decrease in the weight of the testes has been reported consistently for rats (Barnes et al. 1983; Linder et al. 1988; Hess et al. 1991; Rajeswary et al. 2007). In the present study the number of birds having smaller testes in the different treatment groups increased in a dose-related manner. An increase was reported in the testes weight in rats in the first $96 \mathrm{~h}$ followed by a decrease (Nakai et al. 1992). In the present study the quails killed on day 8 of the experiment did show a decrease in the testes weight. Microscopic changes observed in the smaller sized testes of the quails in the present study are similar to those described for carbendazim toxicity in Japanese quails (Aire 2005) and rats dosed with benomyl. Hypospermatocytogenesis and generalized disruption of germinal epithelium in adult male Sprague-Dawley rats have been reported (Carter and Laskey 1982). In adult Wistar male rats a decreased weight of testes, reduced caudal sperm reserves, decreased sperm production and increased number of multinucleated giant cells in seminiferous tubules had been reported (Linder et al. 1988).

Some authors reported sloughing of the immature germ cells at all stages of the cycle in the seminiferous tubules of male rats (Hess et al. 1991; Nakai et al. 1992). The presence of smaller testes with histological evidence of aspermatocytogenesis in two quails administered $1000 \mathrm{mg}$ of benomyl $/ \mathrm{kg}$ body weight, even on day 56 of the experiment, suggested that these two particular birds might have developed an irreversible damage to the testes. However, an increase in the testicular weight and a decrease in number of quails showing histological alterations in benomyl-treated groups in the later stages of the experiment suggested a reversibility of damage to the testes. Reversibility of the testicular changes has been reported in rats (Barnes et al. 1983) while other authors reported benomyl and carbendazim to induce irreversible testicular damage in rats (Carter et al. 1987; Hess and Nakai 2000; Hess et al. 1991).

In mammalian species benomyl and its primary metabolite carbendazim, apart from their effects on male gonadal tissue, are known to produce chromosomal aberrations (Georgieva et al. 1990; Zale sco et al. 1990; Matsuo et al. 1999), teratogenic effects (Hewitt et al. 2005) and suspected as being mutagens (Adhikari and Grover 1988; Bianchi-Santamaria et al. 1997). In the present study single cell gel electrophoresis (alkaline comet assay) was used to detect the ability of benomyl to produce breaks in DNA strands. The comet assay is a rapid and sensitive method for the detection of DNA strand breakage in individual cells induced by a variety of genotoxic agents (Fairbairn et al. 1995). Based on formation of comets as a diffuse collection of DNA material around the nuclear heads, short comet tails and non-significant differences of comet tail lengths from the control groups fed no benomyl, the leukocytes of the quails administered up to $400 \mathrm{mg}$ benomyl $/ \mathrm{kg}$ body weight did not show any evidence of damage to DNA. Development of significantly longer comet tails in birds of $1000 \mathrm{mg} / \mathrm{kg}$ group suggested a break of DNA strands. Benomyl and 
carbendazim have been reported by some workers to produce micronuclei in polychromic erythrocytes and normochromic erythrocytes (Sarrif et al. 1994; Bianchi-Santamaria et al. 1997). A benomyl-induced increase in micronuclei in polychromatic erythrocytes has been reported at $1000 \mathrm{mg} / \mathrm{kg}$ but not at $500 \mathrm{mg} / \mathrm{kg}$ (Seiler 1976). Studies in vitro, however, have suggested that benomyl or its metabolite carbendazim did not result in DNA damage in human lymphocytes (Lebailly et al. 1997) and Chinese hamster ovary (CHOKI) cells (Vigreux et al 1998). DNA strand breaks evidenced by comets produced at $1000 \mathrm{mg}$ benomyl $/ \mathrm{kg}$ in quails suggested that at such dosage benomyl might have some clastogenic activity in the birds. Damage to the chromosome structure has been considered as "inevitable consequence" of aneuploidies that might induce a low level of clastogenicity just as clastogens might induce a low level of aneuploidy (Aardema et al. 1998).

The present study described the toxicopathological effects of benomyl in avian species and also evinced the DNA strand breakage by comet assay at high dose levels $(1000 \mathrm{mg} /$ $\mathrm{kg}$ body weight for 8 days). However, further work is needed to establish the genetic toxicology of benomyl in avian species.

\section{Patologický účinek Benomylu na samce japonských křepelek (Coturnix japonica)}

Cílem této studie bylo zjišt’ování patologických a genotoxických účinků systemického fungicidu Benomilu, [methyl 1-(butyl carbamoyl) -2 benzimidazol karbamát], na samce křepelek japonských (Coturnix japonica). Benomyl (Benlate ${ }^{\circledR}$ DoPont 50\% w/w benomyl) byl 8 po sobě následujících dnů podáván v dávkách $0,100,400$ a $1000 \mathrm{mg} \cdot \mathrm{kg}^{-1}$ do zrní odděleným skupinám křepelek. V závislosti na dávce Benomylu docházelo k významnému poklesu $(\mathrm{p}<0,05)$ př́ijmu potravy, váhy a relativní hmotnosti varlat. U křepelek, kterým byl podán Benomyl, došlo k makroskopickému zmenšení varlat.

Mikroskopicky bylo v seminiferních kanálcích méně spermatocytů, byly pozorovány nekrotické spermatidy a buněčná syncytia. Počet křepelek, u kterých se projevily změny na varlatech se zvyšoval v závislosti na dávce. Tyto změny vymizely po ukončení podávání Benomylu, s výjimkou skupiny s dávkováním 1000 mg Benomylu, kde byly změny stále př́tomny i v době ukončení experimentu (56. den). Prưměrná délka ocasu komety $(\mu \mathrm{m})$ vzniklého cestováním leukocytů v gelu při elektroforéze byla 3,48, 3,24 a 3,29, u skupin po dávkách 0,100 a 400 mg. Průměrné délky ocasů komet při dávce 1000 mg byly 12,03 $\mu \mathrm{m}$, takže byly signifikantně delší ve srovnání s ostatními skupinami, což dokládá porušení řetězce DNA při tomto dávkování. Tyto výsledky poukazují na gonadotoxický efekt benomylu (Benlate®) a možný genotoxický účinek na japonské křepelky v dávce 1000 $\mathrm{mg} \cdot \mathrm{kg}^{-1}$.

\section{References}

AARDEMA MJ, ALBERTINI S, ARNI P, HENDERSON LM, KIRSCH-VOLDERS M, MACKAY JM, SARRIF AM, STRINGER DA, TAALMAN RD 1998: Aneuploidy: a report of an ECETOC task force. Mutat Res 410: 3-79

ADHIKARI N, GROVER IS 1988: Genotoxic effects of some systemic pesticides: in vivo chromosomal aberrations in bone marrow cells in rats. Environ Mol Mutagen 12: 235-242

AIRE TA 2005: Short-term effects of carbendazim on the gross and microscopic features of the testes of Japanese quails (Coturnix coturnix japonica). Anat Embryol (Berl) 210: 43-49

BARNES TB, VERLANGIERI AJ, WILSON MC 1983: Reproductive toxicity of methyl 1-(butylcarbamyol)-2benzimidazole carbamate (benomyl) in male Wistar rats. Toxicology 28: 103-115

BENTLEY KS, KIRKLAND D, MURPHY M, MARSHALL R 2000: Evaluation of thresholds for benomyland carbendazin-induced aneuploidy in cultured human lymphocytes using fluorescence in situ hybridization. Mutat Res 464: 41-51

BIANCHI-SANTAMARIA A, GOBBI M, CEMBRAN M, ARNABOLDI A 1997: Human lymphocyte micronucleus genotoxicity test with mixtures of phytochemicals in environmental concentrations. Mutat Res 388: $27-32$ 
CARTER SD, HESS RA, LASKEY JW 1987: The fungicide methyl 2-benzimidazole carbamate causes infertility in male Sprague-Dawley rats. Biol Reprod 37: 709-717

CARTER SD, LASKEY JW 1982: Effect of benomyl on reproduction in the male rat. Toxicol Lett 11: 87-94

FAIRBAIRN DW, OLIVE PL, O’NEILL KL 1995: The comet assay: A comprehensive review. Mutat Res 339: $37-59$

GEORGIEVA V, VACHKOVA R, TZONEVA M, KAPPAS A 1990: Genotoxic activity of benomyl in different test systems. Environ Mol Mutagen 16: 32-36

HESS RA, NAKAI M 2000: Histopathology of the male reproductive system induced by fungicide benomyl. Histol Histopathol 15: 207-224

HESS RA, MOORE BJ, FORRER J, LINDER RE, ABUEL-ATTA AA 1991: The fungicide Benomyl (methyl 1-(butylcarbamoyl)-2-bebzimidazole carbamate) causes testicular dysfunction by inducing the sloughing of germ cells and occlusion of efferent ductules. Fundam Appl Toxicol 17: 733-745

HEWITT M, MUTCH P, PRATTEN MK 2005: Potential teratogenic effects of benomyl in rat embryos cultured in vitro. Reprod Toxicol 20: 271-280

HURTT ME, MEBUS CA, BOGDANFFY MS 1993: Investigation of the effects of benomyl on rat nasal mucosa. Fundam Appl Toxicol 21: 253-255

LEBAILLY P, VIGREUX C, GODARD T, SICHEL F, BAR E, LETALAER JY, HENRY-AMAR M, GAUDUCHON P 1997: Assessment of DNA damage induced in vitro by etoposide and two fungicides (carbendazim and chlorothalonil) in human lymphocytes with the comet assay. Mutat Res 375: 205-217

LINDER RE, REHNBERG GL, STRADER LF, DIGGS JP 1988: Evaluation of reproductive parameters in adult male Wistar rats after subchronic exposure (gavage) to benomyl. J Toxicol Environ Health 25: 265-298

MATSUO F, NAKAI M, NASU T 1999: The fungicide carbendazim induces meiotic micronuclei in the spermatids of the rat testis. J Vet Med Sci 61: 573-576

McCARROLL NE, PROTZEL A, IOANNOU Y, FRANK STACK HF, JACKSON MA, WATERS MD, DEARFIELD KL 2002: A survey of EPA/OPP and open literature on selected pesticide chemicals III. Mutagenicity and carcinogenicity of benomyl and carbendazim. Mutat Res 512: 1-35

NAKAI M, HESS RA, MOORE BJ, GUTTROFF RF, STRADER LF, LINDER RE 1992: Acute and longterm effects of a single dose of the fungicide carbendazim (methyl 2-benzimidazole carbamate) on the male reproductive system in the rat. J Androl 13: 507-518

RAJESWARY S, KUMARAN B, ILANGOVAN R, YUVARAJ S, SRIDHAR M, VENKATARAMAN P, SRINIVASAN N, ARULDHAS MM 2007: Modulation of antioxidant defense system by the environmental fungicide carbendazim in Leydig cells of rats. Reprod Toxicol 24: 371-380

SARRIF AM, BENTLEY KS, FU LJ, O'NEIL RM, REYNOLDS VL, STAHL RG 1994: Evaluation of benomyl and carbendazim in the in vivo aneuploidy/micronucleus assay in BDF1 mouse bone marrow. Mutat Res 310: 143-149

SEILER JP 1976: The mutagenicity of benzimidazole derivatives. VI. Cytogenetic effects of benzimidazole derivatives in the bone marrow of the mouse and Chinese hamster. Mutat Res 40: 339-347

SINGH NP, MCCOY MT, TICE RR, SCHNEIDER EL 1988: A simple technique for quantification of low levels of DNA damage in individual cells. Exp Cell Res 175: 184-191

VIGREUX C, POUL JM, DESLANDES E, LEBAILLY P, GODARD T, SICHEL F, HENRY-AMAR M, GAUDUCHON P 1998: DNA damaging effects of pesticides measured by the single cell gel electrophoresis assay (comet assay) and the chromosomal aberration test, in CHOK1 cells. Mutat Res 419: 79-90

WARHEIT DB, KELLY DP, CARAKOSTAS MC, SINGER AW 1989: A 90-day inhalation toxicity study with benomyl in rats. Fundam Appl Toxicol 12: 333-345

ZALESCO PA, BARBIERI I, GRAVES JA 1990: Use of a cell hybrid test system to demonstrate that benomyl induces aneuploidy and polyploidy. Mutat Res 242: 335-339 